\title{
Effect of Interest Rate Subsidies on Firm Performance and Investment Behavior during Economic Recession: Evidence from Vietnam*
}

\author{
Tuan-Minh Dinh, Edmund Malesky, Trung-Thanh To and \\ Duc-Thanh Nguyen
}

Received 24 January 2011; accepted 11 December 2012

\begin{abstract}
This paper aims to quantitatively evaluate the microeconomic consequences of the 4-percent interest rate subsidy program, the main component of the Vietnamese Government's economic stimulus package in 2009, which was intended to assist recovery from the global economic and financial recession. Our analyses based on the Provincial Competitive Index 2009 survey and accounting data of firms listed on Vietnam's two stock exchanges show that firms that received subsidized loans were more likely to increase labor, to expand investment and to possess optimistic business plans. However, we find evidence that not all business activity generated by the stimulus led to productivity increases: a non-trivial proportion of subsidized loans were not used to invest in production or expansion, but for speculative activities such as real estate and stock market trading.
\end{abstract}

Keywords: interest rate subsidy, firm performances, firm investment behavior, Vietnamese economy.

JEL classification codes: E65, H25, D21, C25.

doi: $10.1111 /$ asej.12009

\section{Introduction}

Loan subsidy policies are commonly applied by governments around the world. These programs, however, are often targeted at particular demographics or industrial sectors (e.g. subsidies for low-income housing, farmers, students or small business). Vietnam's 4 percent loan subsidy policies in 2009, in response to the

*Dinh (corresponding author): Vietnam Centre for Economic and Policy Research, 144 Xuan Thuy Street, Cau Giay District, Hanoi, Vietnam. Email: dinh.tuanminh@vepr.org.vn. Malesky: Duke University. Department of Political Science, Duke University, 326 Perkins Library, Box 90204, Durham, NC 27708, USA. Email: ejm5@duke.edu. To: Faculty of Economics, National Economics University, 207 Giai Phong Street, Hai Ba Trung District, Ha Noi. Email: totrungthanh@gmail.com. Nguyen: Vietnam Centre for Economic and Policy Research, 144 Xuan Thuy Street, Cau Giay District, Hanoi, Vietnam. Email: nguyen.ducthanh@vepr.org.vn. We wish to acknowledge useful comments on previous drafts by participants at a seminar at the University of Economics and Business, Vietnam National University, Hanoi, and by one anonymous referee. We thank US-AID's Vietnam Competitiveness Initiative for the use of the firm-level data. Financial assistance was provided by a grant from the Vietnam National University, Hanoi for the writing of Vietnam Annual Economic Report 2010. The authors are solely responsible for the views expressed and for any remaining errors. 
global economic crisis, stands out as unique, because it was applied on a very large scale across a broad cross-section of economic sectors. Approximately US $\$ 1$ bn of the 2009 government budget was dedicated to the interest rate subsidy program. When we consider the effect of leverage by lenders in magnifying the scale of the subsidy, the total subsidized credit pumped into the Vietnamese economy was US $\$ 25 \mathrm{bn}$, equivalent to 26.6 percent of the country's 2008 GDP.

The unique attributes of Vietnam's loan subsidy scheme attracted controversy from both local analysts and policy-makers, even before the program was launched. On one side, the policy's supporters argued that the subsidies were necessary to stop the sharp decline in drivers of aggregate demand, such as gross exports and domestic investment (see Tran, H. N., 2008; Tran, X. G., 2008; Cao, 2009). On the other side, opponents contended that Vietnam's 2008 economic contraction was due to economic policies that were generating excess investment through cheap credit to favored, but inefficient, state conglomerates. Under such conditions, argued the opponents, a large-scale loan subsidy policy would generate high inflation and exacerbate trade deficits in subsequent years, by increasing the excess investment inherent in the current economic system (see Nguyen, 2008; Vu, 2008; Vu, Nguyen, Dapice, Pincus and Wilkinson, 2009; Dinh, 2009). Given the heated debate and its massive scale, it is quite surprising that the loan subsidy program did not result in academic attention proportionate to the policy's economic effects or discussion in public forums. Until now, only a few studies have attempted to quantify the effects of policies to stimulate aggregate demand in Vietnam (see Nguyen et al., 2008; Giesecke and Tran, 2009; Nguyen and Ha, 2009). Because these studies were conducted either before or just after the implementation of the stimulus package, however, the authors primarily harnessed descriptive methods to investigate the impact of the subsidy program. To date, there has been no robust quantitative evidence on the true impact of the loan subsidy scheme on business activity and overall economic performance.

In this paper, we address this lacuna with quantitative evaluations of the loan-subsidy programs, based on two unique datasets. The first evaluation uses regression analysis and propensity score matching (PSM) to study the behavior of 8000 Vietnamese enterprises in response to the stimulus, based on the Provincial Competitiveness Index survey (PCI), which is conducted by the Vietnam Chamber of Commerce and Industry and the Vietnam Competitiveness Initiative (see Malesky (2009) for the survey methodology). The second evaluation examines aggregate financial performance of companies listed on the country's two stock exchanges in Ha Noi and Ho Chi Minh City. Our quantitative analyses based on these two datasets allow us to conclude that the loan subsidy scheme had a positive impact on employment, investment and optimism. At the same time, it appears that the stimulus may have increased capital employed in speculative activities over the same time period. This finding implies that some of the subsidized loans leaked into other activities (i.e. real estate or stock market speculation) and was not used for business production or expansion. The main lesson from Vietnam's loan subsidy policy is that such programs can be effective, 
but should be constrained to a short timeframe and should be closely monitored. Otherwise, they risk doing more harm than good and could actually exacerbate deteriorating economic conditions.

The paper is organized as follows. The next section provides a brief literature review of the loan subsidy policy and investment behavior of firms in recession periods. Section III investigates the context of the promulgation and implementation of Vietnam's loan subsidy scheme in 2009. Section IV evaluates the impact of these policies on firm behavior and performance using the PCI 2009 dataset. Section V examines the alteration of economic behavior of listed enterprises based on their official financial reports. Finally, Section VI offers some concluding remarks and policy implications.

\section{Theoretical Background on of Loan Subsidy Policy and Corporate Investment Behavior}

\section{II.1 Theoretical framework}

When providing a loan subsidy, generally, a government establishes a fund to provide credit to recipients with lower interest rates than the prevailing market rate. Such schemes have been quite common globally and are frequently applied by governments to target particular social groups or industries, often as a means of transfer to disadvantaged groups. The economic consequences of such schemes, however, are theoretically controversial.

The economic effects of loan/credit subsidy programs were modeled formally by a large number of scholars during the 1980s, such as Mankiw (1986), Bosworth, Carron and Rhyne (1987), de Meza and Webb (1987), Gale (1990, 1991 ) and Smith and Stutzer (1989). Based on these general models, Dailami and Kim (1994) developed a specific theoretical framework to analyze the effect of loan subsidy policies on corporate investment behavior in a normally functioning economy. Below, we modify the theoretical construction of Dailami and Kim (1994) to assess the effect of loan subsidies on corporate investment behavior during an economic recession.

According to standard neoclassical economics, in a normally functioning economy without a loan subsidy, firms will be satisfied with projects generating marginal rate of return (MRR) equal to marginal cost of capital (MCC), which determines their optimal total investment in productive assets, $I^{*}$. Interestingly, when the loan subsidy policy is implemented, as Dailami and Kim (1994) argue, firms still will not change their investment in productive assets whatever the subsidy level is, because the loan subsidy has no influence on the $M C C$ at $I^{*}$. If firms receive an amount of subsidized loan less than $I^{*}$, the subsidy only allows firms to earn extra income, and does not motivate them to increase their investment in further productive assets. If firms receive an amount of subsidized loan large than $I^{*}$, then they still keep their investments in productive assets at $I^{*}$, and the remaining subsidized capital will be invested in speculative assets, which 
promises a better $M R R$ under the subsidy. To increase firms' productive investment level above than $I^{*}$, the government needs an effective monitoring program to prevent firms from using subsidized loans to invest in risky assets. This requires: (i) continuous supervision of the government, from the beginning to the completion of loan period; and (ii) no collusion between supervising offices and firms. These measures can be very difficult to implement in practice. If any collusion is ignored, firms will consider the tradeoff between potential punishment together with bribes to supervising offices and the difference of returns from investing in productive assets and speculative assets. In sum, the effectiveness of the loan subsidy on investment behavior depends on the quality of supervision provided by regulators.

During an economic recession, however, in the above theoretical framework one must take into account the changing cost structure for firms. During a downturn, the marginal cost of capital tends to increase due to higher interest rates, higher corporate bond yields and lower securities prices. As a result, the optimum investment in productive assets will decline to the level $I x^{*}$, where $I x^{*}<I^{*}$.

Another issue during a global recession is that banks' liquidity requirements will push up short-term interest rates, which increases the cost of working capital for firms and, in turn, increases the cost of existing productive activities. In addition, firms may encounter a sharp drop in global consumption. Combined, these issues could result in the restriction of not only new productive investments, but also a rollback of existing production.

Consequently, when the cost of capital curve shifts upwards due to recession, a short-term loan subsidy will help firms maintain their existing production level. However, this support, as mentioned above, should not have a substantial influence on the investment decisions of firms. Firms still tend to have an investment level lower than or equal to $I x *$, regardless of loans with or without subsidy. Subsidized loans larger than $I x *$ will be exploited for other speculative purposes. To ensure that firms increase their investments to a point larger than $I x^{*}$, the government must have an efficient supervision program.

When the capital market returns to normal conditions, the cost of capital will fall to the expected level $M C C$, and firms will have an incentive to extend their productive investment. In this case, a loan subsidy enables firms to benefit both from working capital and loans with lower interest rates. If they receive a subsidized loan larger than $I^{*}$, they will only invest in production at $I^{*}$, and the remaining capital will be used to invest in speculative assets.

The theoretical framework above generates three hypotheses regarding the 2009 loan subsidy policy in Vietnam:

Hypothesis 1 Short-term loan subsidies should increase firms' cheap working capital, allowing them to continue existing production at a profitable level.

Hypothesis 2 Loan subsidies should not lead to significant investment in expanding production activities beyond previous levels. 
Hypothesis 3 When continued too long and without proper monitoring, loan subsidies will increase investment in speculative assets.

\section{II.2 Previous empirical work on loan subsidies}

In spite of the importance assigned to loan subsidy programs by policy-makers, as revealed by the sizable amount of resources that they absorb, they have received little attention from applied economists. Only a few empirical tests of their effectiveness have been conducted, of which the most notable studies are Gale (1991), Dailami and Kim (1994), del Monte and Scalera (2001) and Patacchini and Rapisarda (2003). Despite the small number of studies, a large range of empirical methods have been applied to test the impact of interest rate subsidies, which have included: quantitative simulation of the effects of credit policies based on the predictions of a formal model (Gale, 1991); OLS regression using panel data (Dailami and Kim, 1994; Patacchini and Rapisarda, 2003); and hazard models with a Weibull distribution (Del Monte and Scalera, 2001). These rigorous studies have demonstrated that loan subsidy programs can have positive effects, but, when not carefully supervised, can have significant negative consequences, including investment in non-productive assets and rent-seeking behavior.

While fascinating, the lessons for researchers and policy-makers are limited by severe selection bias in the choice of loan recipients. None of the subsidy programs considered in the above studies were administered generally, and often included a select group of beneficiaries who were selected for their economic scale or political motivations. Although the authors attempt to address the selection issue, generalizable lessons could be more readily drawn from a loan subsidy program that was offered on a broader scale and where data is fine-grained enough to address selection effects empirically. Vietnam offers such a case.

\section{The Context of Vietnam's Loan Subsidy Policy}

Facing consecutive quarterly declines in GDP in 2008, and feeling the negative influence of the global financial crisis, the Vietnamese Government decided to stimulate the economy with a package of fiscal and monetary policies in early 2009. While fiscal policies such as tax reductions and increases in public expenditures were easily passed, monetary policies were heavily debated by policy-makers.

Controversy was stirred, because in addition to slowing growth, the Vietnam currency (VND) was simultaneously under strong pressure for devaluation due to high inflation (peaking at 28.23 percent on August 2008) and large trade deficits, which had been caused by rapid expansion over the previous 3 years. Some Vietnamese officials were afraid that if the basic interest rate was reduced substantially, like other countries during the recession, the deposit interest rate of the VND would fall in a corresponding fashion, which would lead to a significant 
devaluation of the VND relative to US dollars. In the context of high dollarization in the Vietnamese economy, such a shift might inhibit monetary policy and undermine Vietnam's export potential. As a result, the State Bank of Vietnam decided to only cut the basic interest rate from 8.5 to 7 percent. $^{1}$

As a compromise that would allow them to stimulate the economy while limiting further dollarization, the Vietnamese Government 'invented' the idea of extending an interest rate subsidy to a wide domestic audience. According to an official Vietnamese Government explanation, the interest rate subsidy policy would overcome both the liquidity problem during the economic recession and the threat of domestic currency devaluation due to monetary policy easing. ${ }^{2}$ Loan subsidies would enable firms to access credit with lower interest rates. In addition, commercial banks would be more willing to extend credit, boosting the aggregate demand of the economy. Because firms would be willing to invest capital in production, economic growth would be preserved and even extended in the face of the global shocks. At the same time, official deposit interest rates would remain relatively high, which would ward off a bank run and, consequently, maintain the value of VND.

In January 2009, Vietnam's Prime Minister made formal Decision 131 to stipulate the implementation of the short-term loan subsidy package. ${ }^{3}$ The loan amount granted under the interest rate subsidy scheme immediately soared and 90 percent of the total plan amount was reached after 6 months. The State Bank of Vietnam reported that by 24 December 2009 loans granted under the subsidy package had reached VND412tn (US\$24m or 97 percent of the planned total). Surprisingly for Vietnam watchers, who expected the government to favor state companies, privately-owned domestic companies received approximately 70 percent of the total subsidized loans.

At the end of 2009, when the 4-percent interest rate subsidy package had almost expired, the Prime Minister launched another Decision, which implemented a 2-percent loan subsidy package for medium-term and long-term loans for innovation in production and business development. The maximum loan period was 24 months, beginning on the date of loan receipt in 2010. The government specifically targeted economic sectors such as agriculture, forestry, aquiculture, manufacturing, science and technology, and agricultural trading services for priority access.

1 See the interview with the governor of the State Bank of Vietnam, Nguyen Van Giau, in Vneconomy newspaper issued on 8 February 2010 (Nguyen, 2010).

2 Interview with the Governor of the State Bank of Vietnam, Nguyen Van Giau (ibid.).

3 The main features of Decision 131 stipulating the implementation of the short-term loan subsidy package are: (i) the maximum period for the loan subsidy was 8 months from the date of loan receipt to the end 2009; (ii) the interest rate loan subsidy was 3 percent per year; (iii) funds for the interest rate subsidy scheme were drawn from the state budget, estimated to be approximately VND17 000bn; (iv) the loan subsidy package was designated as follows: 50 percent was for infrastructure development, 25 percent was for agricultural and rural development, 5 percent was for housing and social development, and 20 percent was designated specifically to small and medium size enterprises. 


\section{Impact of the Loan Subsidy Policy on Firm Performance ${ }^{4}$}

The 2009 PCI survey contains 9890 respondents, out of whom 3225 received the 4-percent interest rate subsidy in 2009. ${ }^{5}$ Undoubtedly, this is the best dataset containing information on enterprises receiving the loan subsidy in 2009. Nevertheless, the dataset, drawn from a survey of economic governance at the provincial level, does not provide rich enough data on the loan subsidy, or on the characteristics and the subsequent performance of enterprises after the receipt of the loans. The best available measures are changes in labor and capital used by enterprises after loan receipt. Despite this limitation, the assessment of the impact of the loan subsidy policy on firm activities is still feasible in respect to private investment and employment growth.

\section{IV.1 Methodology and variables}

We use $G$ to denote the expected gain in firm performance due to the interest rate subsidy program:

$$
G=E\left(R_{1 i}-R_{0 i} \mid P_{i}=1\right),
$$

where $P_{i}$ is the $i$ th firm's access to the subsidy, which takes the value 1 if the firm participates in the program, and 0 otherwise, $R_{1 i}\left(R_{0 i}\right)$ is the performance outcome of the $i$ th firm if the firm has access (or does not have access) to the subsidy. $G$ is the conditional mean effect, as it depends on accessing the subsidy program, which is called the treatment effect. To estimate $G$, there are two methods that we apply in this study.

The first method is to estimate the regression:

$$
R_{i}=a+b P_{i}+c X_{i}+e_{i},
$$

where $X_{i}$ is a matrix of observable characteristics of the $i$ th firm that could determine the firm's performance. The regression itself controls for the different characteristics of firms, where the estimated coefficient $b$ is the program's impact on firms' performance, when other factors are held constant. Nevertheless, estimates using this method may be biased, because of unobserved heterogeneity

4 The content of this section was originally released in a report submitted to the Vietnam Competitiveness Initiative (VNCI) on January 2010. We would like to thank the VNCI for kindly providing us a full dataset of the PCI 2009 survey to conduct relevant analyses.

5 Unfortunately, only 7787 respondents were able to answer all the questions necessary for the full empirical analysis. The key issue was that a large portion of respondents were new entrants, having just started operations in 2009, so it was impossible to calculate their change rates as a result of the stimulus. We were forced to leave these 1500 firms out of the analysis, but they do not present any threat of selection bias as we are primarily interested in how the stimulus affected existing firms. To study this, we compared PCI data with the full population of Vietnamese firms based on data from the National Tax Authority and the General Statistical Office. In terms of legal form, labor size, investment and age, the sample of firms used in the survey is highly representative. 
among firms. That is, unobservable features of the individual firms or their managers may be associated with both the probability of receiving the investment and the subsequent firm performance. It is easy to see why: more entrepreneurial managers may be both more likely to apply for loans and expand their businesses. Because these features cannot be measured or controlled for, standard OLS regression may assign a portion of the variance caused by those underlying factors to the coefficient on the loan treatment $(b)$. Consequently, we would estimate a larger effect of the loan than would be observed if the distribution of loans was randomized. Under such circumstances, the most appropriate design would be a two-stage instrumental variables analysis, rather than standard OLS.

Because a theoretically appropriate instrument was not available, however, we make use of an alternative technique, PSM, to ensure the robustness of results to different specifications. PSM seeks to recover the underlying experimental ethos of regression analysis, where a researcher computes the difference in performance outcomes between participants (the treatment group) and a comparison group or control group that is selected to be balanced on all observable covariates. This allows us to address the non-random selection into the stimulus program and to identify the unbiased effects of loan access. We implement the PSM strategy by following the five steps below: ${ }^{6}$

1 We estimate a probit model of program access as a function of the variables that are likely to determine the participation, then calculate the predicted probability of access (propensity scores).

2 For each firm in the participant sample, we find five firms in the non-participant sample that have the closest propensity scores (the five nearest neighbors).

3 We compute the mean value of outcomes of the five nearest neighbors and the difference between that mean and the actual value of the treated firm. This difference represents the estimated gain due to access to the loan program.

4 The mean of all individual-firm gains represents the general impact of the stimulus package on firms' performance.

5 This final result can also be conditioned by covariates of interest to learn more about the heterogeneous impact of the stimulus package across different types of respondents.

Table 1 describes the measurement of performance outcomes $\left(R_{i}\right)$ that will be used to evaluate the loan effectiveness. In addition, we must be conscious of potential omitted variables that may be associated with both accessing loans and business expansion $\left(X_{i}\right)$. Without controlling for these factors (described in Table 1) we risk attributing too much explanatory power to the stimulus. In particular, we control for: (i) characteristics of the manager, including his/her education and previous relationship with the government (which, as Malesky and Taussig (2008) show, can significantly affect access to bank credit); (ii) characteristics of the firm, including its size, sector, legal form, orientation toward 6 For more information on the PSM technique and its utility, see Rosenbaum and Rubin (1983) and Imbens and Wooldridge (2008). 
Table 1 Definition and measurement of variables

\begin{tabular}{|c|c|c|}
\hline & Variables & Definition and measurement \\
\hline \multirow[t]{10}{*}{$\mathrm{X}_{\mathrm{i}}$} & Education & $\begin{array}{l}\text { Three-point scale measuring whether manager has }(0) \text { no higher } \\
\text { education; (1) a bachelor's degree; and (2) a master's degree }\end{array}$ \\
\hline & Relationship & $\begin{array}{l}\text { The sum of former connections the manager has to local and central } \\
\text { governmental officials, including his or her role as a (i) former } \\
\text { government official; (ii) former manager of state-owned enterprise; } \\
\text { and (iii) former military official (see Malesky and Taussig, 2008). }\end{array}$ \\
\hline & Former SOE & $\begin{array}{l}\text { A measure of whether the enterprise is a former state-owned } \\
\text { enterprise, which has been recently equitized (privatized). }\end{array}$ \\
\hline & Ownership types & $\begin{array}{l}\text { Dummy variables with four types: (i) sole proprietorship; (ii) limited } \\
\text { liability; (iii) joint stocks; and (iv) all other types (household } \\
\text { firms/cooperatives) }\end{array}$ \\
\hline & $\begin{array}{l}\text { Government } \\
\text { shareholder }\end{array}$ & $\begin{array}{l}\text { A dichotomous variable, capturing whether the firm is a joint stock } \\
\text { company with shares held by a government actor. }\end{array}$ \\
\hline & Listed & $\begin{array}{l}\text { A dichotomous measure of whether the firm is listed on national } \\
\text { stock exchanges. }\end{array}$ \\
\hline & Sectors & $\begin{array}{l}\text { Dummy variables with four sectors: (i) } \\
\text { industry/manufacturing/construction; (ii) service/commerce; (iii) } \\
\text { agriculture/forestry/aquaculture; and (iv) mining and all others }\end{array}$ \\
\hline & Firm size & $\begin{array}{l}\text { Dummy variables with four sizes: (i) super-small; (ii) small; (iii) } \\
\text { medium; and (iv) large. The size categories are defined following } \\
\text { Decree 56/2009. }\end{array}$ \\
\hline & Market orientation & $\begin{array}{l}\text { Dummy variable with two orientations: (1) inward-oriented if the } \\
\text { percentage of domestic sale is more than } 50 \text { percent and (0) } \\
\text { export-oriented otherwise. }\end{array}$ \\
\hline & $\begin{array}{l}\text { Regional } \\
\text { characteristics }\end{array}$ & $\begin{array}{l}\text { All PCI sub-indices that explain variation in performance across } \\
\text { provinces. These could control for the regional characteristics that } \\
\text { impact on firms' outcomes. }\end{array}$ \\
\hline \multirow[t]{6}{*}{$\mathrm{R}_{\mathrm{i}}$} & $\begin{array}{l}\text { Change in } \\
\text { employment }\end{array}$ & $\begin{array}{l}\text { Change in the ordered categories of employment between the year } \\
2008 \text { (before the stimulus package was introduced) and the time of } \\
\text { survey (after the package was introduced; see footnote 2). }\end{array}$ \\
\hline & $\begin{array}{l}\text { Change in number } \\
\text { of employment }\end{array}$ & $\begin{array}{l}\text { Change in the number of workers from the year } 2008 \text { (before the } \\
\text { stimulus package was introduced) and the time of survey (after the } \\
\text { package was introduced) }\end{array}$ \\
\hline & Change in capital & $\begin{array}{l}\text { Change in the ordered categories of capital between the year } 2008 \\
\text { (before the stimulus package was introduced) and the time of } \\
\text { survey (after the package introduced; see footnote 3). }\end{array}$ \\
\hline & $\begin{array}{l}\text { Business plan in } \\
\text { next } 2 \text { years }\end{array}$ & $\begin{array}{l}\text { Six-point scale measuring firm investment plans over the next } 2 \\
\text { years, ranging from } 1 \text { (close business) to } 6 \text { (considerably increase) } \\
\text { (see footnote } 4 \text { ). }\end{array}$ \\
\hline & Expand business & $\begin{array}{l}\text { Dichotomous measure of whether a firm intends to expand business } \\
\text { over the next } 2 \text { years. }\end{array}$ \\
\hline & $\begin{array}{l}\text { Expanded business } \\
\text { premises }\end{array}$ & $\begin{array}{l}\text { Dichotomous measure of whether a firm purchased land in the past } \\
\text { year. }\end{array}$ \\
\hline
\end{tabular}

Note: PCI, Provincial Competitiveness Index survey; SOE, state-owned enterprise. ${ }^{\mathrm{a}} \mathrm{We}$ use number of employment as the criterion to classify firm size because the capital variables in the datasets do conform to classifications in this Decree. 
domestic or international markets, privatization history, and whether the firm is listed on national stock markets; and (iii) measures of the business environment in which the firm operates, such as governance, infrastructure quality and proximity to major domestic markets.

\section{IV.2 Regression method and results}

Table 2 presents the regression of change in employment based on the stimulus. Model 1 simply presents the bivariate correlation between the stimulus and labor growth. Model 2 controls for characteristics of the manager, including his/her education and previous role in the Vietnamese Government, and whether the firm is a former SOE. Model 3 uses size fixed effects to test whether the effect of the stimulus holds within groups of similarly-sized firms. Models 4 and 5 add sector fixed effects and legal form dummies to ensure that the effect of loan access is robust within major sectors or particular ownership types. Model 5 adds a control for whether the firm predominantly sells to the domestic sector (i.e. is inward-oriented). Model 6 uses the PCI measures of economic governance at the province level, as corruption, transparency, infrastructure or proximity to big markets of a province could also influence loan access and firm performance. Finally, Model 7 removes provincial variance using a set of provincial dummies to compare the effect of the stimulus within similarly-situated provinces.

Throughout the regressions, access to loans remains sizable and statistically significant at the 95-percent confidence level. In the fully-specified Model 7, the coefficient of interest, access to the interest-rate subsidy scheme, is 3.87 , implying that participants in the loan program hired almost 4 more workers than nonparticipants. This effect is substantively enormous: on a national level, 4 employees per recipient firm would generate 276800 jobs, equating to roughly 20 percent of the increase in the labor force in 2009. Looking at this another way, the median size of private firms in Vietnam is between 5 and 9 employees (according to the PCI), meaning that subsidies led to firm-level increases in employment of between 44 and 80 percent.

Beyond labor we might expect that access to the subsidy will affect investment decisions and expansion plans. Table 3 builds on the analysis in Table 2 by replicating the fully-specified Model 7 with a range of new dependent variables, including: a further test of change in employment using differences in employment size recorded on an eight-point scale in the PCI survey between 2008 and 2009 (Model 2); ${ }^{7}$ change in investment size on an eight-point scale

7 The following question was asked in Section A of the 2009 PCI Survey Instrument in order to measure the employment size of the business: What was the employment size of your firm? 1. Less than 5 people; 2. Between 5 and 9 people; 3. Between 10 and 49 people; 4. Between 50 and 199 people; 5. Between 200 and 299 people; 6. Between 300 and 499 people; 7. Between 500 and 1000 people; 8. Above 1000 people. 


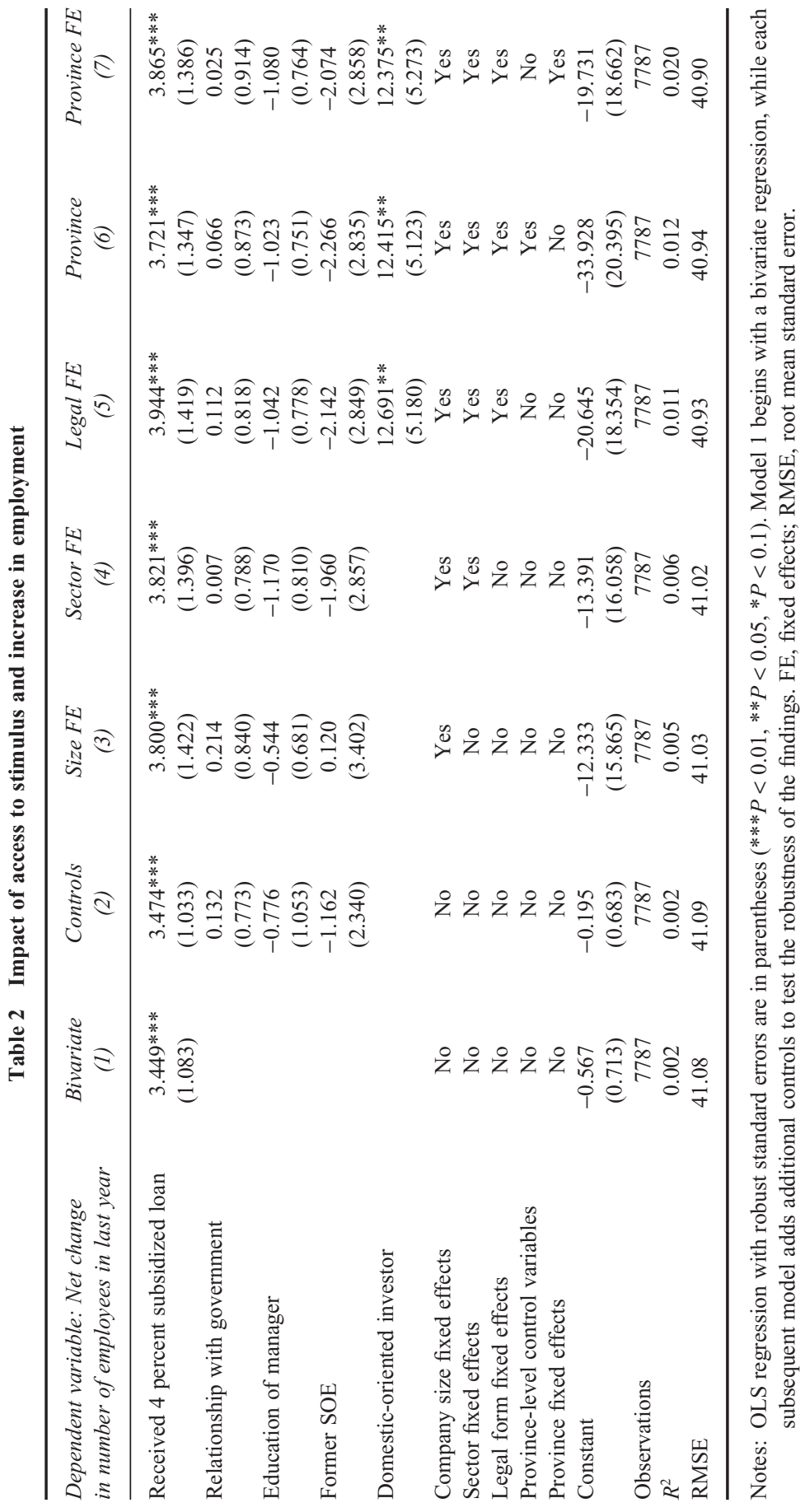

(C) 2013 The Authors 


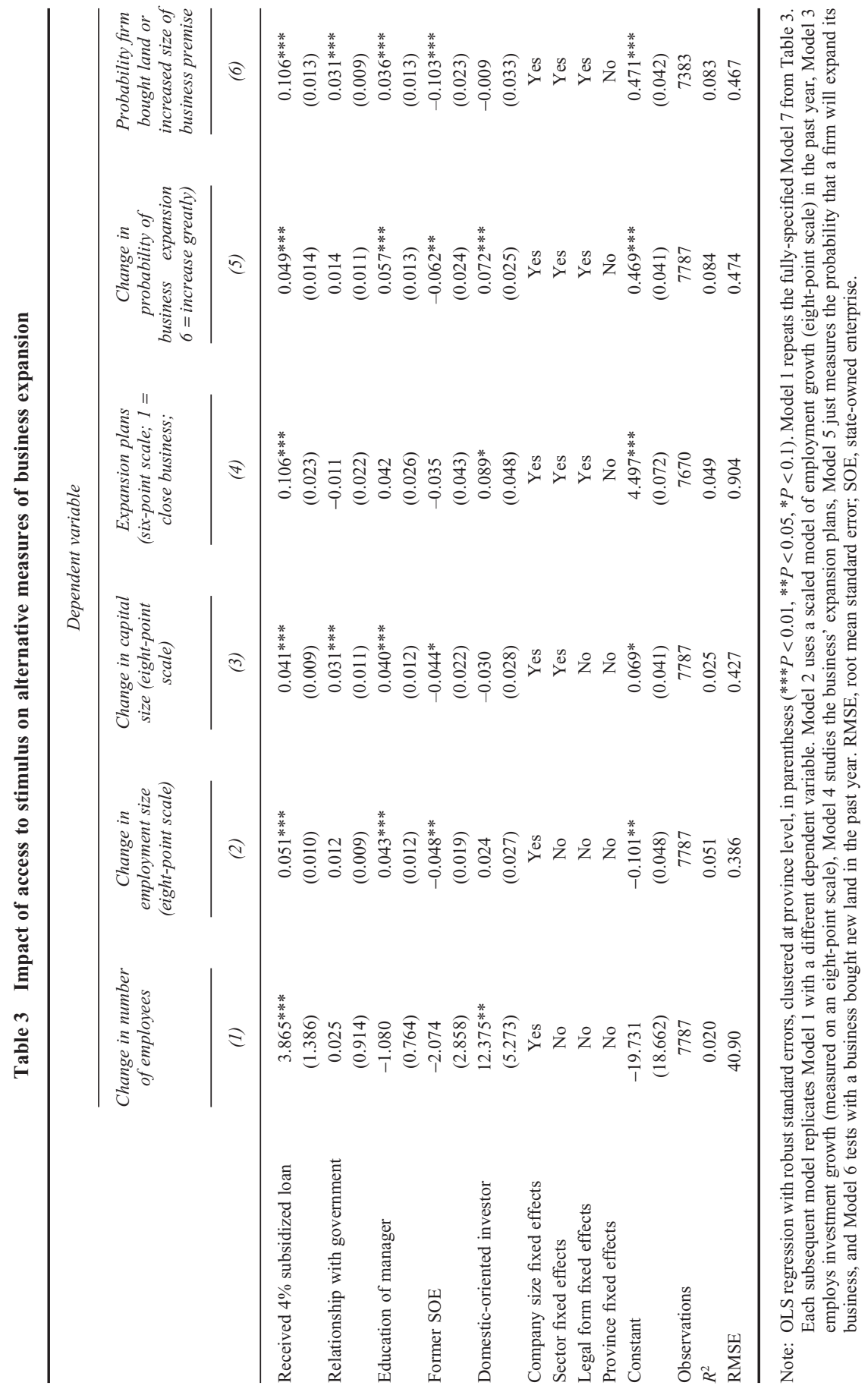


(Model 3); ${ }^{8}$ a firm's self-reported plans for the next 2 years on a six-point scale (Model 4); ${ }^{9}$ the probability that a firm answered that it wanted to expand its business (Model 5) ${ }^{10}$ and whether a firm expanded its business premises through real estate purchase or construction (Model 6).

Table 3 demonstrates that, controlling for a range of confounders, accessing the stimulus is strongly associated with all forms of business expansion. Firms receiving the loan increased their employment size by approximately 0.5 points on the eight-point scale and approximately 0.4 points on the eight-point capital scale, ${ }^{11}$ and score one-tenth of a point higher on the expansion scale, which translates into a 5-percent higher probability of answering that the business intends to expand over the next 2 year. It is worrisome, however, is that firms receiving the stimulus were also 11 percent more likely to expand their business premises, which is a problem, as it might indicate that some of the stimulus leaked into speculative real estate investment, rather than more productive forms of investment.

While striking, these effects are likely overstated due to the bias caused by the unobserved heterogeneity described above. In the following subsection, we use PSM to reduce endogeneity bias and offer more precise results.

\section{IV.3 Results of propensity score matching}

Table 4 shows the probit model as the first step of the PSM, in which the determinants of access to the stimulus program are identified. The table indicates that a large number of factors are associated with access to the stimulus, which might lead to bias in the naïve results depicted in Tables 2 and 3 above. Most worrisome is the fact that owners of firms who had previous experience in government, military or state-owned enterprises were approximately 3 percent more likely to receive loans (concurring with Malesky and Taussig (2008)), while the education of the owner had a negative effect: an owner with an MBA was 2

8 The following question was asked in Section A of the 2009 PCI Survey Instrument in order to measure the capital size of the business: What was the total equity capital of your firm? 1 . Under VND0.5bn; 2. Between VND0.5 and VND1.0bn; 3. Between VND1bn and VND5bn; 4. Between VND5bn and VND 10bn; 5. Between VND10bn and VND50bn; 6. Between VND50bn and VND200bn; 7. Between VND200 and VND500bn; 8. Above VND500bn.

9 The following question was asked in Section A of the 2009 PCI Survey Instrument in order to measure the optimism/expansion plans of the operation: Which statement best characterizes your firm's investment plans over the next 2 years? 1. Plan to close this business; 2. Plan to considerably reduce the size of operations; 3 . Plan to reduce the size of operations; 4 . Will continue operating at present size; 5. Plan to increase the size of operations; 6. Plan to considerably increase the size of operations.

10 For this measure, the six-point expansion plan measure was reduced to a dichotomous measure by coding whether the firm planned to expand (i.e. it answered 5 of 6 ) on the six-point scale as a 1 , while other values were coded as zero).

11 When re-estimated in ordered probit, this implies a 2-percent probability of moving from 3 to 4 on the labor scale and 4-percent probability of moving from 3 to 4 on the capital scale. Both are significant at the 0.01 level. 
Table 4 Determinants of selection into stimulus treatment

Determinants of selection

Dependent variable: Firm

Relationship with government received $4 \%$ subsidized loan

Education of manager

$0.029 * *$

$(0.012)$

$-0.024 *$

(0.013)

Former SOE

0.017

(0.025)

Government shareholder

$-0.056^{* *}$

(0.028)

Listed on stock exchange

0.204

(0.125)

Size of company (reference category $=$ large)

Micro

$-0.401 * * *$

(0.031)

Small

$-0.253 * * *$

(0.037)

Medium

$-0.109 * * *$

(0.032)

Sector of operation (reference category $=$ manufacturing)

Service

0.023

$(0.015)$

Agriculture

Natural resources

Legal form (reference category $=$ sole proprietorship)

Limited liability company

Joint stock company

$-0.032$

(0.024)

Other

$-0.175 * * *$

(0.034)

Province fixed effects

Yes

Constant

$-0.567$

(0.713)

Observations

7787

$\mathrm{P}$

0.346

Pseudo $R^{2}$

0.0855

Log likelihood

$-4594$

Notes: Probit model. Coefficients display marginal probability of selection into stimulus with robust standard errors, clustered at province level, in parentheses $(* * * P<0.01, * * P<0.05, * P<0.1)$.

percent less likely to obtain a loan than an owner with a bachelor's degree. These effects indicate that loan access was not random. Thankfully, the government did not show bias toward equitized firms, and appeared, in fact, to be biased against firms in which it owned shares. 
Firms in the agriculture, forestry and aquaculture sector have the highest probability of access to the subsidy, presumably because one of the package's stated objectives was to help these sectors. ${ }^{12}$ Meanwhile, mining firms had less access to the stimulus than all other sectors. Micro-firms with less than 10 workers appear to have encountered difficulties in accessing subsidized loans, while large firms (over 300 employees) tended to be favored. Medium-sized firms (50-200 employees in the trade sector and 200-300 employees in other sectors) were significantly less likely than large firms to obtain a loan (10 percent less likely), but had a significantly higher probability than micro and small firms.

Table 5 presents the evaluation of the stimulus policy's effectiveness using PSM. All numbers in the table are understood as the mean difference in outcomes between participant treated firms and the comparison group, which represents the marginal effect of the program. For each dependent variable, we present three results. The first result (Unmatched) is the naive $t$-test between the treatment and the control group. TET is the average treatment effect on the treated, where we compare the treatment group to the five nearest neighbors in the control group, which are selected from the propensity scores derived from Table 4. Finally, we bootstrap standard errors to account for the fact that PSM does not properly calculate standard errors when the treatment variable is a prediction. After accounting for selection into the treatment group, we find that the impact of the stimulus on business expansion is almost exactly the same, and in the case of employment and business plans, is actually slightly larger than the naïve estimates. These results are extraordinary, indicating that the stimulus was successful in its targeting and stated goals, considerably boosting employment, while also contributing to greater investment and business optimism. On the downside, however, the leakage into real estate investment remains a strong possibility, even after accounting for selection, as recipients were 10 percent more likely to add land to their business premises.

\section{IV.4 Heterogeneous effects of the stimulus policy}

In Table 6, we study the heterogeneous effect of the stimulus treatment by replicating Model 1 (Table 5) within each category of firms. The dependent variable remains the absolute changes in employment: the only continuous dependent variables. The table clearly demonstrates that the stimulus had positive and significant effects among a wide swath of firms. Nevertheless, the labor increases resulting from the stimulus were larger for joint stock companies than other legal forms. Manufacturing and services had greater labor increases than other sectors, with manufacturing slightly (but not significantly) outpacing services. Finally, small and medium-sized firms appeared to benefit more than larger operations from access to the subsidy. No significant differences in

12 See Decree 497 dated 17 April 2009 


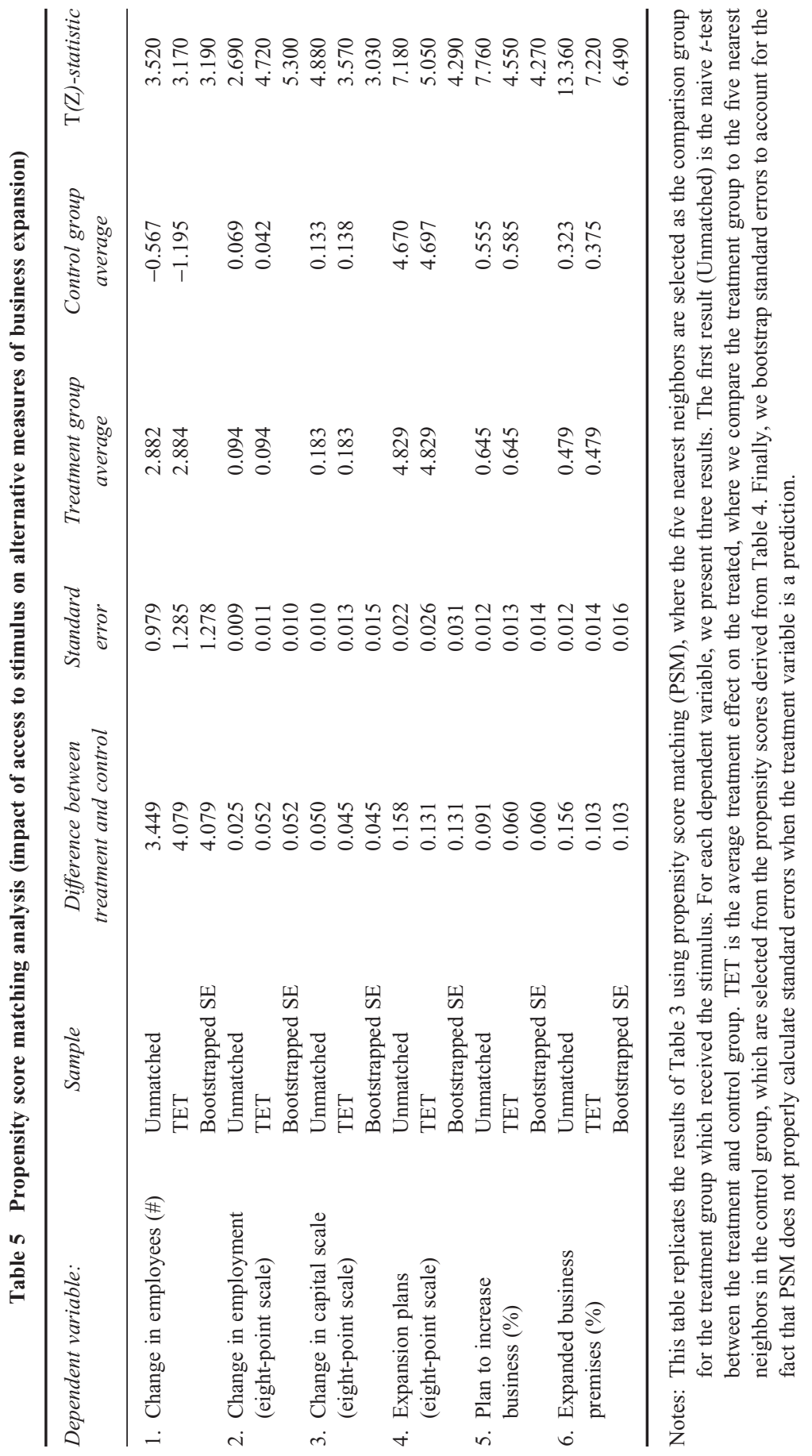


Table 6 Heterogeneous effects of stimulus (by legal form, sector, size and other firm characteristics)

\begin{tabular}{lcccc}
\hline Type of firm & $T E T$ & $S E$ & & $95 \% C I$ \\
\hline Legal form of enterprise & & & & \\
Sole proprietorship & 0.62 & 0.22 & $(0.2$ & $1.04)$ \\
Limited liability & 3.2 & 0.17 & $(2.88$ & $3.53)$ \\
Joint stock & 3.92 & 0.28 & $(3.36$ & $4.47)$ \\
Sector & & & & \\
Manufacturing & 3.75 & -2.83 & $(9.29$ & $-1.8)$ \\
Services & 3.27 & 1.47 & $(0.39$ & $6.14)$ \\
Construction & -1.94 & -1.01 & $(0.03$ & $-3.91)$ \\
Agriculture & 4.82 & -3.34 & $(11.36$ & $-1.73)$ \\
Mining & 0.83 & -19.48 & $(39.02$ & $-37.4)$ \\
Employment size & & & & \\
Micro & 0.47 & 0.26 & $(-0.04$ & $0.99)$ \\
Small & 2.36 & -0.05 & $(2.45$ & $2.27)$ \\
Medium & 8.02 & 0.61 & $(6.82$ & $9.23)$ \\
Large & 10.87 & -8.1 & $(18.97$ & $22.03)$ \\
Personal relationship with authorities & & & & \\
No & 3.77 & -2.7 & $(9.07$ & $-1.53)$ \\
Yes & 1.89 & -0.19 & $(2.26$ & $1.52)$ \\
Equitized former state-owned enterprise & & & & \\
No & 3.19 & -0.58 & $(4.33$ & $2.05)$ \\
Yes & 0.31 & -4.85 & $(9.82$ & $-9.2)$ \\
Exporting firm & & & & \\
No & 2.08 & -19.75 & $(40.78$ & $-36.6)$ \\
Yes & 3.2 & 1.26 & $(0.72$ & $5.68)$ \\
Owner has bachelor's degree & & & & \\
No & 2.59 & -0.29 & $(3.17$ & $2.02)$ \\
Yes & 3.75 & -0.94 & $(5.59$ & $1.9)$ \\
\hline & & & & \\
\hline
\end{tabular}

Source: Provincial Competitiveness Index 2009. This table replicates Model 1 (Table 5) within each category of firms. The dependent variable is the change in employment. SE, bootstrapped standard error; TET, treatment effect on the treated; $95 \%$ CI, 95\% confidence interval.

the TET are observed between exporters and domestic-oriented operations, greenfield versus equitized firms, and connected versus non-connected entrepreneurs. Interestingly, the stimulus actually appeared to have a negative effect on the construction industry, where treated firms added less labor than firms that did not receive a loan. Once again, this may indicate the negative effect of leakage into non-productive activities, such as real estate investment. Caution is warranted with these heterogeneous results, however, because of the limited number of observations in some categories.

\section{Impact of Loan Subsidy Policies on Firms Listed on Stock Exchanges}

Both methods of analysis based on the PCI 2009 survey reveal the positive impact of the 4-percent interest rate subsidy package on employment and capital changes 
in the private sector. However, these methods could not be used to compute the true size of the package's impact on investment, because the variables of capital in the survey are in the form of ordered scales rather than continuous values, allowing for only rough estimation of the total effects. The analysis also implies that some loans leaked into speculative assets, but this cannot be tested directly. After all, expansion of business premises can imply a healthy and legitimate project as well as a speculative one. Moreover, the PCI did not ask any questions about the use of the stimulus for stock market investment. In other words, the above analysis only provides clear evidence for Hypothesis 1. To assess Hypotheses 2 and 3 satisfactorily, we utilize data from the financial reports of listed companies on the two stock exchanges in Hanoi and Ho Chi Minh City.

\section{V.1 Methodology}

Out of a total of 490 firms listed on the two Stock Exchanges in Ha Noi and Ho Chi Minh City at the end of 2009, 165 are analyzed. The sample is selected simply by picking all non-financial firms (i.e. not including banks, investment funds and securities companies) from the 490 listed firms that have completed financial reports since the first quarter of 2007.

Although we do not have detailed information on how these listed firms benefit from the loan subsidy policies, we make the conservative assumption that once the package was launched, at least a portion of the listed firms received direct benefits. This assumption is reasonable because large and medium-sized private firms were the most likely to receive loans according to the PCI analysis above. Furthermore, it is difficult to separate the benefits that listed firms gain directly from the loan subsidy policies from benefits gained from other elements of the economic stimulus package. However, it is highly likely that listed firms benefited to a greater degree from the loan subsidy than from the other stimulus components, which directly targeted small and medium businesses. ${ }^{13}$ Consequently, our analysis of the fluctuation of aggregate financial indices of listed firms will give us additional insight into the impact of the loan subsidy on business performances and the investment behavior of Vietnamese firms.

Besides applying well-known financial indicators, such as the liquidity ratio (ratio of cash to short term debts), asset turnover (AT), return on assets (ROA) and return on equity (ROE), to measure the business performance of firms, we use the structure of capital, including working capital, productive capital and speculative capital, as an index to evaluate listed firms' investment behavior. These types of capital are defined by Dailami and Kim (1994) as follows:

13 Other fiscal stimulus programs were also introduced in 2009 , such as a credit guarantee for small and medium enterprises, deferment of Corporate Income Tax (CIT) for 9 months, 30-percent CIT reduction for small and medium enterprises, and 50-percent VAT reduction in 2009 (see Giesecke and Tran (2009) for a detailed description of the whole stimulus package). 
Working capital: Cash + Receivables (short-term and long-term) + Other shortterm assets.

Productive capital: Fixed asset + Inventory $+h *$ Real estate investment. Speculative capital: Financial investment (short-term and long-term) + Other long-term assets $+(1-h) *$ Real estate investment, where $h$ is a parameter denoting the proportion of the real estate investment category that can be attributed to productive use.

To calculate productive capital and speculative capital we need to estimate the parameter $h$. However, estimating $h$ is a complicated process that requires a copious amount of longitudinal data (e.g. see Dailami and Kim, 1994). As Vietnam's stock market and real estate markets are relatively new, time-series data are not available for a large number of indicators before 2007 . We address this issue by using reasonable imputations based on the extant literature on Korea during a similar period of economic development. Based on the experience of Korea during 1984-1988, when the proportion of estate assets used for speculative purpose was 86.5 percent (Dailami and Kim, 1994), we assign the rate of 80 percent for this kind of asset in our case, as we assume Vietnam's investment environment during 2007-2009 is comparable to Korea's in the mid-1980s. Indeed, this rate does not influence greatly the structure of assets because, on average, during the period Q1:2007 to Q4:2009, the assets in the category 'estate investment' of the balance sheets account for only 0.66 percent of the total assets of the listed firms in the sample.

\section{V.2 Analytical results}

The aggregate financial indexes of 165 listed companies on Vietnam's two Stock Exchanges are presented in Figure 1 (Panels A-E). In general, they show that the loan subsidy policy introduced in early 2009 had a positive correlation with the performance of these firms, strengthening Hypothesis 1. Panel B depicts a downtrend in all three performance indexes from the second quarter of 2007 to the first quarter of 2009. The AT ratio, the ROA ratio and the ROE ratio declined from 0.33 to $0.24,0.11$ to 0.09 , and from 0.06 to 0.04 , respectively, during this period. When the loan subsidy policy was carried out, these ratios gradually recovered and reached the approximate levels of the second quarter of 2007.

The loan subsidy policy had a positive impact on the listed firms' performance in the sense that they were no longer deprived of working capital and began to borrow capital from commercial banks for production activities. Panel A shows that firms faced difficulty in mobilizing working capital after the first quarter of 2008, when the tight monetary policy was implemented to control inflation. As a result, the liquidity ratio fell sharply from 0.327 in Q4:2007 to 0.184 in Q2:2008. When the economic stimulus package was carried out, however, the ratio started to increase, rising from 0.221 in $\mathrm{Q} 4: 2008$ to 0.289 in $\mathrm{Q} 1: 2009$ and 0.312 in Q4:2009. 
Figure 1 Performance and investment behavior of vietnamese firms listed on stock markets: (a) ratio of cash to cash to short-term debts, Q1:2007-Q4:2009; (b) measures of business performance, Q1:2007-Q4:2009; (c) indicators for equity and loan mobilization, Q1:2007Q4:2009; (d) structure of assets, Q1:2007-Q4:2009; and (e) indicators of asset movements $(\mathrm{Q} 4: 2008=100)$
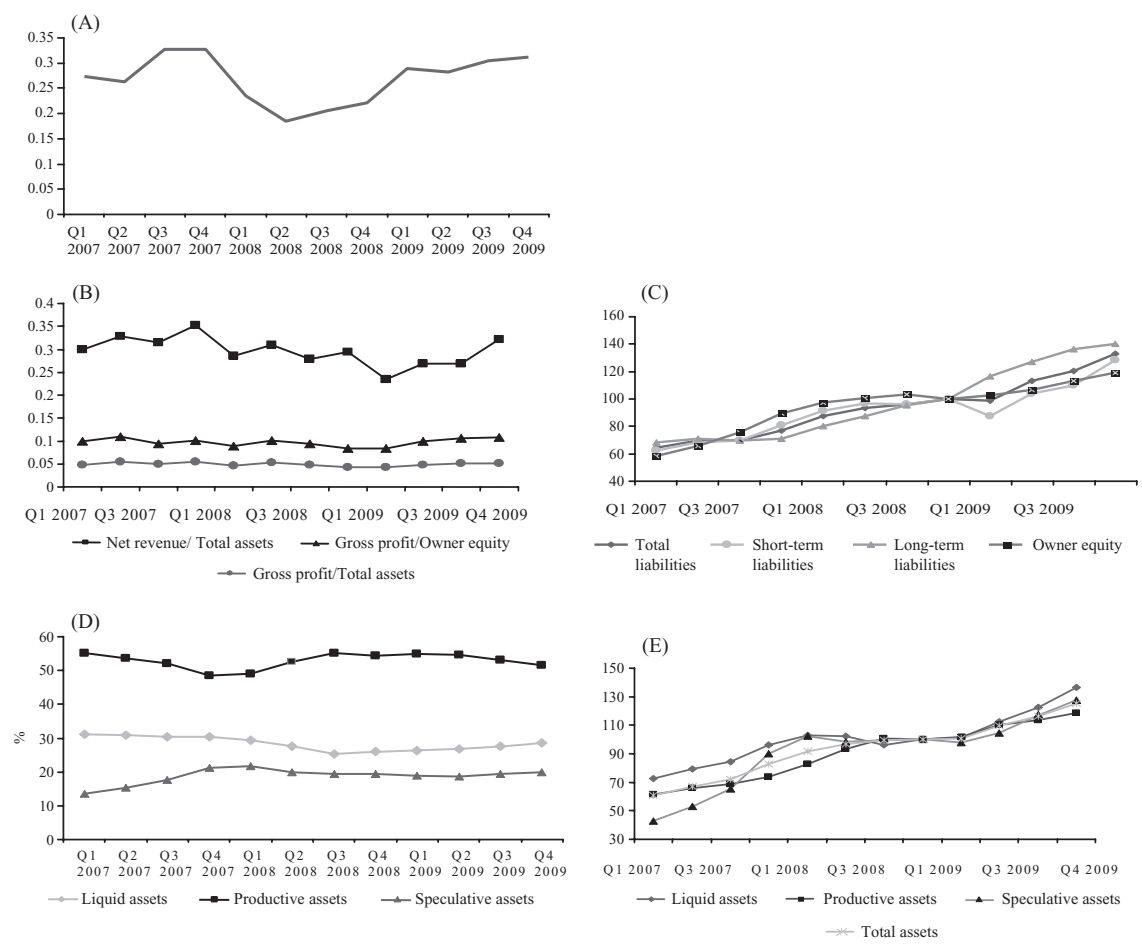

In parallel, the capital mobilized by the firms through debt, especially in the form of short-term loans, moderately increased. Panel $\mathrm{C}$ represents the movement of total capital and debt of the listed firms from Q1:2007 to Q4:2009. Q4:2008 is selected as the reference point, with the value of 100 for all indicators. During the recession period, between Q1:2008 and Q4:2008, the growth rate of ownership equity and debt remained constant as the marginal cost of capital was extremely high. When the stimulus policy was introduced in Q1:2009, the listed firms boosted their remobilization of capital via loans and the issuance of corporate securities. The total outstanding debt of the sample increased by 34.5 percent between Q1:2009 and Q4:2009. The growth rate of short-term debt peaked at 46.2 percent during this period, compared to the rate of 0.9 percent during the same period of 2008. Similarly, the ownership equity increased by 16.3 percent between Q1:2009 and Q4:2009.

The availability of subsidized loans changed the investment behavior of the listed firms. In 2009, under the catalyst of the stimulus policy, the structure of 
three of these assets returned to the level at the end 2007 (see Panel D). Although the amount of three kinds of assets increased during this period, the amount of working assets increased at the highest rate (36.7 percent from Q4:2008 to Q4:2009), followed by speculative assets (27.7 percent), and, finally, by productive assets (18.8 percent). An increasing trend resumed for the speculative assets, and was especially evident during the second half of 2009 (see Panel E).

Changes in the structure of assets and different growth paths of each asset type before and during the implementation of loan subsidy policy have two implications. First, the expansion of productive assets did not last long after Q2:2009, which implies that firms did not use the loans to invest in productive activities for sustained periods, even when the subsidy policy was still maintained. This may be due to the fact that the weighted marginal capital cost of the economy during the second half of 2009 increased much more than in the first half of 2009. According to the IMF's financial database, the interest rate on Vietnamese treasury bills increased from the lowest rate of 6 percent in February 2009 to 8.2 percent in June 2009 and 9 percent in September 2009; and the deposit rate increased correspondingly from 6.54 to 7.5 and 8.13 percent, respectively (IMF, 2010). At the same time, the stock exchange index, VN-INDEX, increased from the lowest level of 235 points in late February 2009, to 450 points at the end of June 2009 and 570 point at the end of September 2009. This evidence appears to support Hypothesis 2 that the loan subsidy policy helped the listed firms to increase investment in productive activities, but only for a short period of time.

Second, firms tended to put money into risky activities when the cheap credit was still available, while the opportunities for productive activities were limited. The increasing trend of speculative assets since the second quarter of 2009 strongly supports Hypothesis 3 on the increase in investment in speculative assets after receipt of subsidized loans. This demonstrates the dark side of the stimulus policies, as it is difficult and costly to ensure that subsidized loans are used for productive activities, especially when these loan-subsidizing programs are conducted over a short period, as in 2009.

\section{Conclusions}

There is no doubt that the decisive introduction and quick implementation of a large stimulus package was the most important economic factor influencing the Vietnamese economy in 2009. More than \$US24m was pumped into the economy to subsidize the 4-percent interest rate for both short-term and long-term business loans during 2009. This stimulus policy had an enormous impact on all aspects of the Vietnamese economy. Therefore, drawing lessons from this experience is critical not only for academic but also practical purposes. This research is the first quantitative evaluation of the impact of the stimulus policy on individual-level firm performance.

Two different assessment approaches, based on two different datasets, lead to similar results: the loan subsidy helped firms to increase working capital, to keep 
their businesses in operation and to hire additional labor. Given the recession during 2009, such government support truly had a positive social and economic impact on the Vietnamese business community. Our calculations in this paper show that the loan subsidy program reached approximately 30 percent of the firms in the sample, and each firm that received a loan subsidy hired, on average, 4 more workers.

Nevertheless, during the second half of 2009, there was a tendency for firms to restrict their investments in productive activities while extending their investments in speculative activities, such as real estate and financial derivatives. As we show formally, the marginal cost of capital of the economy determines the investment behavior of the firms in productive activities. When the marginal cost of capital declined substantially in Q1:2009, it encouraged firms to put money into productive activities. However, as the marginal cost of capital returned to a high rate in Q3:2009, firms tended to move their investments to risky activities. Highly speculative investments during the last quarter of 2009, in turn, led to a surge in asset price markets (e.g. real estate, securities, gold and foreign currencies) and increased inflationary pressure, causing further macroeconomic imbalances. The termination of the loan subsidy program at the end 2009, therefore, was the right decision by the Vietnamese authorities.

The most important lesson from the implementation of Vietnam's loan subsidy program during 2009 is that a loan subsidy program may have a positive economic impact if it is limited to a short period and is well monitored. As the research in the present paper shows, the loan subsidy program was quite useful during the first half of 2009, when subsidized loans were used for predominantly productive activities. However, after that point, firms tended to use the low interest rate loans for speculative purposes, leading to vulnerability in the macroeconomic environment.

\section{References}

Bosworth, B. P., A. S. Carron and R. Rhyne, 1987, The Economics of Federal Credit Programs. Brookings Institution, Washington, DC.

Cao, S. K., 2009, Gói kích cầu đang 'chuyển mình', interviewed by journalists Viet Anh and Hoang Lan on Vnexpress (20 May 2009) [online; cited 1 March 2010]. Available from URL: http:// vnexpress.net/gl/kinh-doanh/2009/05/3ba0f351/.

Dailami, M. and E. H. Kim, 1994, The effects of debt subsidies on corporate investment behavior: The Korean experience. Pacific-Basin Finance Journal, 2, pp. 1-21.

Del Monte, A. and D. Scalera, 2001, The life duration of small firms born within a start-up programme: Evidence from Italy. Regional Studies, 35, pp. 11-21.

de Meza, D. and D. C. Webb, 1987, Too much investment: A problem of asymmetric information. Quarterly Journal of Economics, 101, pp. 281-92.

Dinh, T. M., 2009, Để kích cầu không trở thành bao cấp. Interviewed by journalist Doan Trang on TuanVietNam Online (13 May 2009) [online; cited 1 March 2010]. Available from URL: http:// tuanvietnam.vietnamnet.vn/de-kich-cau-khong-tro-thanh-bao-cap).

Imbens, G. and J. Wooldridge, 2008, Recent developments in the econometrics of program evaluation. IZA Discussion Paper No. 3640. IZA, Bonn, Germany. 
IMF (International Monetary Fund), 2010, Vietnam's Financial Statistics. International Monetary Fund, International Financial Statistics, Washington, DC.

Gale, W. G., 1990, Federal lending and the market for credit. Journal of Public Economics, 42, pp. $177-93$.

Gale, W. G., 1991, Economic effects of federal credit programs. American Economic Review, 81, pp. $133-52$.

Giesecke, J. A. and H. N. Tran, 2009, An economic analysis of Vietnam's fiscal stimulus package. Tạp chi Phát triên Kinh tế-xã hội Việt Nam, 58, June 2009.

Malesky, E. and M. Taussig, 2008, Where is credit due? Companies, banks, and locally differentiated investment growth in Vietnam. Journal of Law, Economics, and Organization 25, pp. 535-78.

Malesky, E., 2009, The Vietnam Provincial Competitiveness Index: Measuring economic governance for private sector development. 2009 Final Report, Vietnam. Competitiveness Initiative Policy Paper \#14. US AID's Vietnam Competitiveness Initiative and Vietnam Chamber of Commerce and Industry, Hanoi.

Mankiw, N. G., 1986, The allocation of credit and finance collapse. Quarterly Journal of Economics, 101, pp. $455-70$.

Nguyen, D. T., 2008, Thận trọng với gói kích cầu 1 tỉ USD, Sai gon tiep thi newspaper (5 December 2008).

Nguyen D. T, T. Bui, T. A. Pham, T. M. Dinh, B. C. Bui and M. H. Duong, 2008, Về chính sách chông suy thoái ở Việt Nam hiện nay: Chính sách kích cầu. VEPR Policy Discussion Series CS-04/2008.

Nguyen, T. N. and T. H. D. Ha, 2009, Đánh giá hiệu quả của chính sách kích cầu chống suy giảm kinh tế ở Việt Nam. Tap chí Ngân hàng, 24, December.

Nguyen, V. G., 2010, Lãi suât, tỷ giá . . . dưới góc nhìn Thống đốc, interviewed by journalist Nguyen Hoai on Vneconomy (8 February 2010) (online; cited 1 March 2010). Available from URL: http://vneconomy.vn/20100208020940992P0C6/chinh-sach-lai-suat-ty-gia-duoi-goc-nhin-thongdoc.htm

Rosenbaum, P., and D. Rubin, 1983, The central role of the propensity score in observational studies for causal effects. Biometrika, 70, pp. 41-55.

Patacchini, G. and E. Rapisarda, 2003, A study of the effectiveness of credit subsidies: Evidence from a panel of Italian Firms. University of Oxford, Department of Economics Working Paper Series, reference 153. University of Oxford, Oxford.

Smith, B. and M. Stutzer, 1989, Credit rationing and government loan programs: A welfare analysis. AREUEA Journal (American Real Estate and Urban Economics Association), 17, pp. 177-93.

Tran, H. N., 2008. Nên thêm tiền cho kích cầu kinh tế, on Tuoi Tre online (10 December) (online; cited 1 March 2010). Available from URL: http://tuoitre.vn/Kinh-te/291958/nen-them-tien-cho-kichcau-kinh-te.html

Tran, X. G., 2008, Chống suy giảm kinh tế: Bàn quá lâu sẽ mất cơ hội, interviewed by journalist Le Nhung on Vietnamnet online (30 December) (online; cited 4 April 2010). Available from URL: http://vnn.vietnamnet.vn/chinhtri/2008/12/821189/).

Vu, T. T. A., 2008, Coi chừng hai nguy cơ. Tuoi Tre Newspaper (4 December 2008).

Vu, T. T. A., X. T. Nguyen, D. Dapice, J. R. Pincus and B. H. Wilkinson, Thay đổi cơ câu: Giải pháp kích thích có hiệu lực duy nhất. Fulbright Vietnam's Discussion Paper No. 4 (released on 1 January 2009). 